\title{
Formulation and evaluation of embelin emulgel for topical delivery
}

\author{
Mahendran Sekar, Nur Asyikin Ismail \\ Department of Pharmaceutical Chemistry, Faculty of Pharmacy and Health Sciences, Universiti Kuala Lumpur \\ Royal College of Medicine Perak, Ipoh - 30450, Perak, Malaysia
}

\begin{abstract}
Background: Embelin is an isolated compound from Embelia ribes and well known for its potent antioxidant and anti-inflammatory properties. However, so far, embelin has not been explored into a topical dosage form due to its hydrophobic nature. Emulgel is a recently developed formulation and emerged as a promising topical delivery system for the delivery of hydrophobic drugs. Aim: The aim of the study to formulate emulgel of embelin and tested for its antioxidant and anti-inflammatory properties. Materials and Methods: The emulsion was prepared and incorporated in a gel base. The formulations were evaluated for physicochemical properties and tested for in vitro antioxidant activity using 2, 2-Diphenyl-1-picrylhydrazyl method. The formulated emulgels were also tested for inhibition of albumin denaturation and lipoxygenase inhibition to evaluate its in vitro anti-inflammatory activity. Results and Discussion: Both the formulated Emulgels (F1 and F2) were looks a purple creamy with a smooth homogeneous texture and glossy appearance. The formulated embelin emulgel showed potent antioxidant and moderate anti-inflammatory properties that is water soluble gel. Conclusion: This embelin emulgel will be further developed into a commercial standard and tested for in vivo studies to confirm its anti-inflammatory properties.
\end{abstract}

Key words: Antiinflammatory, antioxidant, Embelia ribes, embelin, emulgel, topical delivery

\section{INTRODUCTION}

$\mathrm{E}$ mbelin is a naturally occurring alkyl substituted hydroxy benzoquinone and a major constituent of Embelia ribes Burm. (Family: Myrsinaceae). The plant has been reported to possess antioxidant properties in diabetic animals and anti-inflammatory to relieve rheumatism and fever. ${ }^{[1,2]}$ Embelin showed antifertility, ${ }^{[3]}$ antiimplantation, ${ }^{[4]}$ antitumor, ${ }^{[5]}$ antioxidant, analgesic anti-inflammatory, ${ }^{[6,7]}$ hepatoprotective, ${ }^{[8]}$ wound healing, ${ }^{[9]}$ antibacterial, ${ }^{[10]}$ antidiabetic, ${ }^{[11]}$ and anticonvulsant activities ${ }^{[12]}$ Embelin also reported to be used for the treatment of neurological disorders and inflammatory bowel disease. ${ }^{[13,14]}$

Earlier studies in our laboratory reported that embelin has significant antioxidant, analgesic, and anti-inflammatory properties..$^{[6,15]}$ However, so far, there is no formulation which has been done due to its hydrophobic nature. Recent studies indicated that emulgel has been emerged as a promising drug delivery system for the delivery of hydrophobic drugs. Emulgel is a semisolid dosage forms, obtained when gel and emulsion combined together ${ }^{[16]}$ Rachit et al., 2012, ${ }^{[17]}$ reported that mefenamic acid emulgel can be used as an anti-inflammatory analgesic agent for topical drug delivery. Emulgels for topical applications have several promising properties such as being thixotropic, greaseless, easily spreadable, easily removable, emollient, nonstaining, long shelf life, biofriendly, transparent, and pleasing appearance. ${ }^{[18]}$

The topical analgesic and anti-inflammatory preparations are available in the market as different dosage forms including gels, creams, semisolids, emulsions, patches, aerosols, and foams that are applied on or around the painful site. These topical preparations are made up of synthetic chemicals and produce side effect on the consumers. Hence, in the present study, we are interested to formulate a natural emulgel using embelin as an active ingredient and evaluate for its in vitro antioxidant and anti-inflammatory properties.

\section{Address for correspondence: \\ Dr. Mahendran Sekar, Department of Pharmaceutical Chemistry, Faculty of Pharmacy and Health Sciences, Universiti Kuala Lumpur Royal College of Medicine Perak, Ipoh - 30450, Perak, Malaysia. \\ Phone: 006-0163346653/006-05-2536634. \\ E-mail: mahendransekar@unikl.edu.my}

Received: $19-06-2018$

Revised: 21-12-2018

Accepted: 16-01-2019 


\section{MATERIALS AND METHODS}

\section{Plant Material}

The berries of Embelia ribes were purchased from the local Market in Perak, Malaysia and authenticated.

\section{Extraction and Isolation of Embelin}

Coarsely powdered berries of Embelia ribes (500 g) were exhaustively extracted with $n$-hexane by cold extraction method $(3 \times 500 \mathrm{ml})$. After $72 \mathrm{~h}$, the extracts were concentrated to dryness in a rotary evaporator under reduced pressure and controlled temperature $\left(40-50^{\circ} \mathrm{C}\right)$. The residue so obtained was subjected to column chromatography over silica gel (100-200 mesh), and elution with benzene yielded an orange colored powder, ${ }^{[6]}$ which on crystallization with ether afforded orange plates of embelin (2,5-dihydroxy3-undecyl-1,4-benzoquinone, yield $12.5 \mathrm{~g}, 2.5 \%$ ). It was found to be homogenous by high-performance thin-layer chromatographic (HPTLC) when separated using the solvent system ethyl acetate:benzene (70:30). It was characterized by comparing its melting point, infrared (IR), nuclear magnetic resonance (NMR), and MS data with literature values. ${ }^{\left[{ }^{6}\right.}$

\section{Formulation of Embelin Emulge|[19-21]}

The emulgel was made in two steps. The first step was by making of oil in water emulsion and base of gel. The second step was by mixing the emulsion and gel base together. The oil phase emulsion made by dissolving Span 20, embelin and butylated hydroxytoluene in olive oil. Meanwhile, the water phase made by dissolving Tween 60 in distilled water. The menthol was dissolved in 96\% ethanol and then blended into propylene glycol. After that, the oil phase was added to the water phase and followed by the addition of a mixture of mentholethanol-propylene glycol. Then, the mixture was stirred vigorously until emulsion formed. The gel was made by mixing the carbomer in distilled water and stirred until completely dispersed. Next, sodium hydroxide was dissolved in distilled water and added to the gel base carbomer then stirred until a thick gel base is formed. After that, the emulsion was mixed into the base gel by adding gradually and stirred vigorously until a homogeneous mass of emulgel is formed [Figure 1]. The composition of two different formulations has been shown in Table 1.

\section{Evaluation of Formulated Embelin Emulgel}

\section{Physical examination}

The formulated embelin emulgel was evaluated visually for its color, appearance, and consistency. Along with that organoleptic test, homogeneity, and $\mathrm{pH}$ also tested.

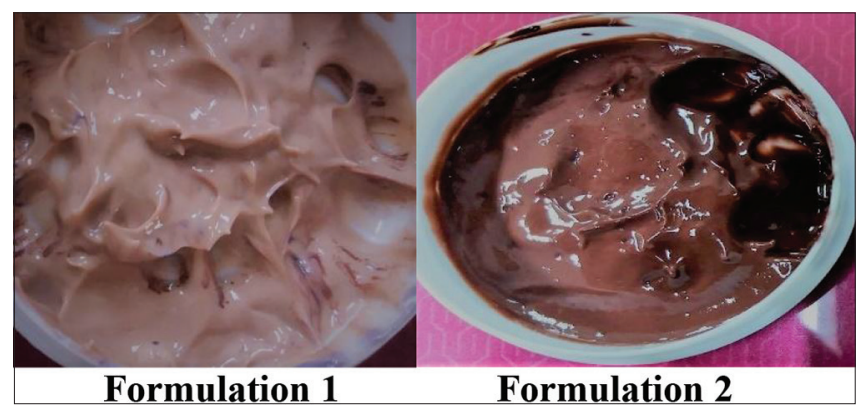

Figure 1: Embelin emulgel

\begin{tabular}{lcc}
\multicolumn{2}{c}{ Table 1: Composition of embelin emulgel } \\
Ingredients & \multicolumn{1}{c}{$\begin{array}{c}\text { Concentration (\%) (w/w) } \\
\text { formulations }\end{array}$} \\
\cline { 2 - 3 } & Formulation 1 (F1) Formulation (F2) \\
\hline Embelin & 1.0 & 3.0 \\
Olive oil & 5.0 & 5.0 \\
Propylene glycol & 5.0 & 5.0 \\
Menthol & 1.0 & 1.0 \\
96\% Ethanol & 3.0 & 3.0 \\
NaOH & 0.6 & 0.6 \\
Carbomer & 2.0 & 2.0 \\
Span 20 & 1.4 & 1.4 \\
Tween 40 & 3.6 & 3.6 \\
BHT & 0.03 & 0.03 \\
Distilled water up to & q.5 & q.5 \\
\hline
\end{tabular}

BHT: Butylated hydroxytoluene

\section{Organoleptic test}

The embelin emulgel was kept for 8 weeks at low temperature, room temperature, and high temperature. The appearance such as color, pearlescence, and roughness was observed and graded.

\section{Homogeneity}

The formulation was tested for homogeneity by visual appearance and touch.

\section{pH test}

The $\mathrm{pH}$ value of $1 \%$ aqueous solution of embelin emulgel was measured using digital $\mathrm{pH}$ meter.

\section{In vitro antioxidant activity by 2, 2-diphenyl-1- picrylhydrazyl (DPPH) radical scavenging method}

A $100 \mu$ aliquot of the different concentrations of embelin and emulgel formulations along with standards were added to $2 \mathrm{ml}$ of DPPH in methanol solution $(100 \mu \mathrm{M})$ and incubated at $37^{\circ} \mathrm{C}$ for $20 \mathrm{~min}$. After that, the absorbance of each solution was determined at $490 \mathrm{~nm}$ using UV-visible spectrophotometer. ${ }^{[22]}$ The percentage inhibition was calculated as follows: 
Percentage inhibition $=[($ Abs control - Abs sample $) \times 100) /$ (Abs control)].

\section{In vitro Anti-inflammatory Activity of the Formulated Embelin emulgel}

\section{Inhibition of albumin denaturation}

The anti-inflammatory activity of the formulated embelin emulgel has been evaluated by albumin denaturation method. The reaction mixture consisted of test formulations and $1 \%$ aqueous solution of bovine serum albumin fraction, $\mathrm{pH}$ of the reaction mixture was adjusted using a small amount of $1 \mathrm{~N} \mathrm{HCl}$. The samples then incubated at $37^{\circ} \mathrm{C}$ for $20 \mathrm{~min}$ and then heated to $51^{\circ} \mathrm{C}$ for $20 \mathrm{~min}$, after cooling the samples the turbidity were measured at $660 \mathrm{~nm}$ using a UV-visible spectrophotometer. $^{[23]}$ The percentage inhibition of protein denaturation was calculated as follows:

Percentage inhibition $=[($ Abs control - Abs Sample $) \times 100) /$ (Abs control)].

\section{Lipoxygenase Inhibitory Action}

Anti-lipoxygenase activity was studied using linoleic acid as a substrate and lipoxidase as an enzyme. Test samples were

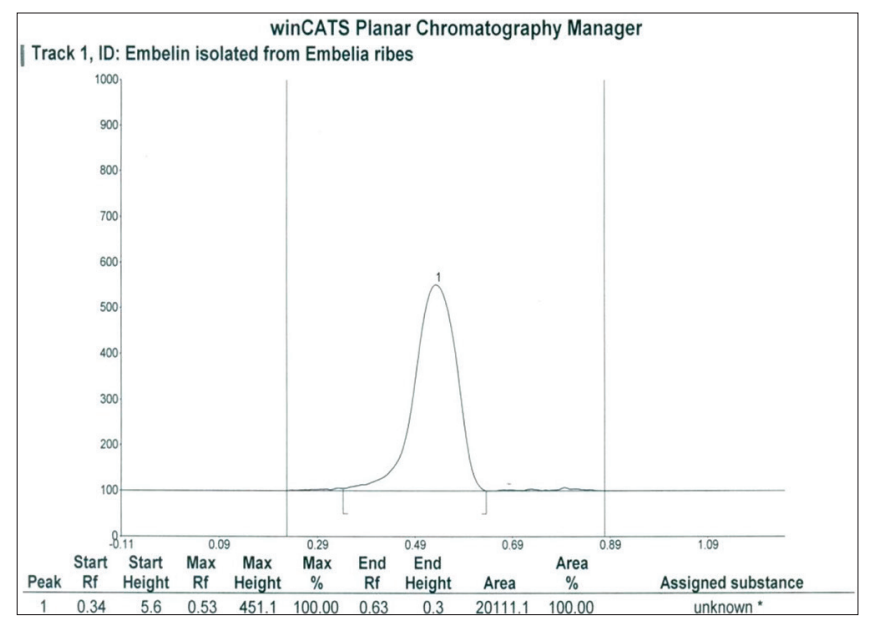

Figure 2: High-performance thin-layer chromatographic spectrum of embelin (1) dissolved in $0.25 \mathrm{ml}$ of $2 \mathrm{M}$ borate buffer $\mathrm{pH} 9.0$ and added $0.25 \mathrm{ml}$ of lipoxidase enzyme solution and then incubated for $5 \mathrm{~min}$ at $25^{\circ} \mathrm{C}$. After that, $1.0 \mathrm{ml}$ of linoleic acid solution was added, mixed well and absorbance were measured at $324 \mathrm{~nm}$ using UV-visible spectrophotometer. ${ }^{[24]}$ Indomethacin was used as reference standard. The percentage inhibition of protein denaturation was calculated as follows:

Percentage inhibition $=[($ Abs control-Abs sample $) \times 100) /$ (Abs control)].

\section{Statistical Analysis}

Each experiment was carried out in three replicates; the mean of variable \pm standard deviation was calculated.

\section{RESULTS}

Embelin was isolated from the berries of Embelia ribes, found to be homogenous by HPTLC [Figure 2] when separated using the solvent system ethyl acetate:benzene $\left(70: 30, R_{f}=0.53\right)$. Obtained as orange plates mp $141-143^{\circ} \mathrm{C}$; yield $12.5 \mathrm{~g}, 2.5 \%$; IR $v_{\max }(\mathrm{KBr}) \mathrm{cm}^{-1}: 3309(\mathrm{O}-\mathrm{H}), 2920$, $2849(\mathrm{C}-\mathrm{H}), 1746(\alpha, \beta$ - unsaturated $\mathrm{C}=\mathrm{O}), 1615(\mathrm{C}=\mathrm{C})$ [Figure 3]; ${ }^{1} \mathrm{H}$ NMR (400 MHz, $\mathrm{CDCl}_{3}$ ) $\delta: 7.68$ (s, 2H, -OH), 6.00 (s, 1H, H-6), 2.44 (t, 2H, H-1'), 1.47 (m, 2H, H-2'), $1.25-1.30\left(\mathrm{~m}, 16 \mathrm{H}, \mathrm{H}-3^{\prime}\right.$ to $\left.10^{\prime}\right), 0.88$ (t, 3H, H-11' $)$; Negative ESI-MS: m/z calculated for 294.18, Found: 293 [M-H] ${ }^{-1}$.

\section{Physical Appearance}

Emulgel formulations (F1 and F2) were looks a purple creamy with a smooth homogeneous texture and glossy appearance. The results have been shown in Table 2 .

\section{In vitro Antioxidant Activity}

Embelin showed potent antioxidant activity with a percentage of inhibition value $91.66 \pm 3.68$ at $125 \mu \mathrm{g} / \mathrm{ml}$ in the DPPH method. The formulations 1 and 2 showed potent antioxidant activity with a percentage of inhibition value $50.12 \pm 2.00$

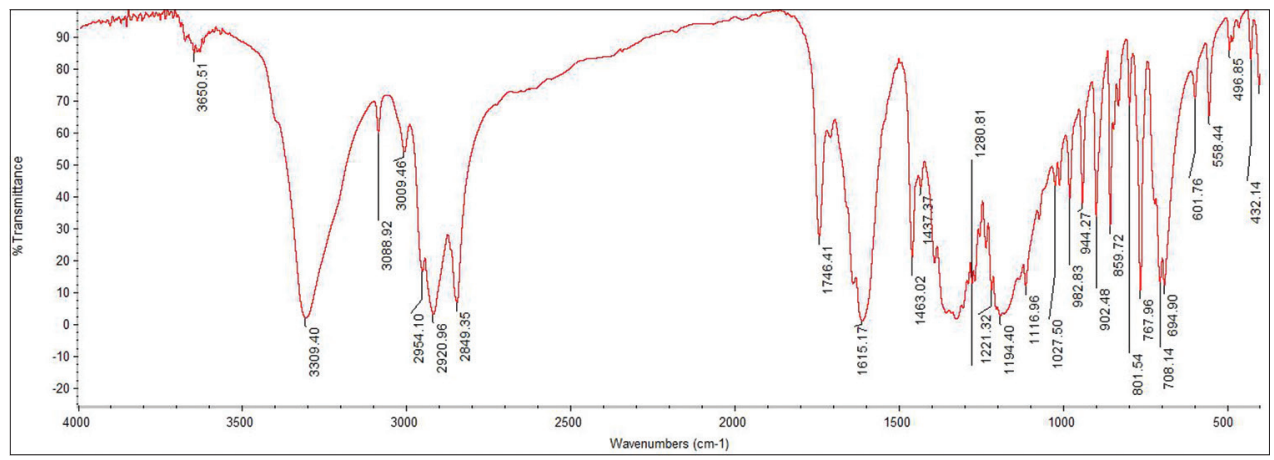

Figure 3: Infrared spectrum of embelin 


\begin{tabular}{lll}
\multicolumn{2}{c}{ Table 2: } & $\begin{array}{c}\text { Physicochemical properties evaluation on } \\
\text { formulated Emulgel }\end{array}$ \\
\hline Parameters & Formulation 1 & Formulation 2 \\
\hline Color & Light purple & Dark purple \\
$\mathrm{pH}$ & 7.8 & 7.6 \\
Homogeneity & Good & Good \\
Appearance & No color changes & No color changes \\
Consistency & Good & Good \\
Phase separation & None & None \\
Odor & Good & Good \\
Spreadability & Good & Good \\
After feel & Good & Good \\
Removal & Easy & Easy \\
Stability & Stable in tested temperature
\end{tabular}

Table 3: In vitro antioxidant activity by DPPH method

\begin{tabular}{|c|c|c|c|}
\hline \multirow{2}{*}{$\begin{array}{l}\text { Concentration } \\
(\mu \mathrm{g} / \mathrm{ml})\end{array}$} & \multicolumn{3}{|c|}{$\%$ Inhibition } \\
\hline & Embelin & Formulation 1 & Formulation 2 \\
\hline 1000 & & $50.12 \pm 2.00$ & $84.88 \pm 2.49$ \\
\hline 500 & & $33.97 \pm 2.93$ & $75.68 \pm 4.58$ \\
\hline 250 & & $16.81 \pm 1.94$ & $57.26 \pm 3.65$ \\
\hline 125 & $91.66 \pm 3.68$ & -- & $44.72 \pm 3.30$ \\
\hline 62.5 & $73.15 \pm 4.81$ & -- & $30.58 \pm 2.16$ \\
\hline 31.25 & $50.25 \pm 2.06$ & -- & -- \\
\hline 15.60 & $21.69 \pm 1.53$ & -- & -- \\
\hline 7.80 & -- & -- & -- \\
\hline 3.90 & -- & -- & -- \\
\hline 1.95 & -- & -- & -- \\
\hline $\begin{array}{l}\text { Ascorbic } \\
\text { acid }(10 \mu \mathrm{g} / \mathrm{ml})\end{array}$ & $92.45 \pm 3.82$ & & \\
\hline Rutin $(10 \mu \mathrm{g} / \mathrm{ml})$ & $48.25 \pm 2.50$ & & \\
\hline
\end{tabular}

and $84.88 \pm 2.49$ at $1000 \mu \mathrm{g} / \mathrm{ml}$, respectively. Formulation 2 showed a higher percentage of inhibition when compared to formulation 1 in all the tested concentrations. However, standard ascorbic acid and rutin showed higher inhibition at low concentration when compared to embelin and its emulgel formulations. The results were shown in Table 3.

\section{In vitro Anti-inflammatory Activity}

As part of the investigation on anti-inflammation activity, the ability of embelin and formulated emulgels (F1 and F2) for inhibition of protein denaturation was studied. It was effective in inhibiting heat-induced albumin denaturation. Maximum inhibition of $47.65 \pm 4.49,10.34 \pm 4.58$, and 31.08 \pm 4.61 was observed at $1000 \mu \mathrm{g} / \mathrm{ml}$ for embelin, F1 and F2, respectively [Table 4]. The lower concentrations did not show

\begin{tabular}{llcc}
\multicolumn{3}{l}{$\begin{array}{c}\text { Table 4: Effect of embelin and its emulgel on albumin } \\
\text { denaturation }\end{array}$} \\
\cline { 2 - 4 } $\begin{array}{l}\text { Concentration } \\
(\mu \mathrm{g} / \mathrm{ml})\end{array}$ & \multicolumn{3}{c}{ \% Inhibition } \\
\hline 1000 & $47.65 \pm 4.49$ & $10.34 \pm 4.58$ & $31.08 \pm 4.61$ \\
500 & $40.87 \pm 1.40$ & -- & $24.94 \pm 3.61$ \\
250 & $34.93 \pm 2.37$ & -- & -- \\
125 & $27.95 \pm 4.22$ & -- & -- \\
Aspirin $(100 \mu \mathrm{g} / \mathrm{ml})$ & $64.58 \pm 4.25$ & & \\
\hline$--:$ No inhibition. Values are expressed as mean $\pm \mathrm{SD}(n=3)$.
\end{tabular}

Table 5: Effect of embelin and its emulgel on lipoxygenase inhibitory action

\begin{tabular}{lccc} 
Concentration & \multicolumn{3}{c}{$\%$ inhibition } \\
\cline { 2 - 4 }$(\boldsymbol{\mu} \mathrm{g} / \mathrm{ml})$ & Embelin & Formulation 1 & Formulation 2 \\
\hline 1000 & $60.28 \pm 2.85$ & -- & $30.65 \pm 1.40$ \\
500 & $43.58 \pm 2.55$ & -- & $17.07 \pm 1.50$ \\
250 & $17.63 \pm 2.05$ & -- & -- \\
Indomethacin & $80.25 \pm 4.86$ & & \\
$(100 \mu g / m l)$ & & \\
\hline --: No inhibition. Values are expressed as mean $\pm S D(n=3)$
\end{tabular}

significant inhibition. Aspirin, a standard anti-inflammatory drug, showed the maximum inhibition of $64.58 \pm 4.25$ at the concentration of $100 \mu \mathrm{g} / \mathrm{ml}$ when compared with control.

In lipoxygenase inhibitory action, embelin and its emulgel formulations (F1 and F2) have been checked at 250, 500, and $1000 \mu \mathrm{g} / \mathrm{ml}$ concentrations. Maximum inhibition of $60.28 \pm 2.85$ and $30.65 \pm 1.40 \%$ was observed at $1000 \mu \mathrm{g} / \mathrm{ml}$ for embelin and F2, respectively [Table 5]. Formulation 1 does not show any inhibition up to $1000 \mu \mathrm{g} / \mathrm{ml}$ concentration. The standard indomethacin showed $80.25 \pm 4.86$ of percentage inhibition at a concentration of $100 \mu \mathrm{g} / \mathrm{ml}$.

\section{Stability Test}

Both the formulated emulgels (F1 and F2) were found to be stable upon storage for 3 months, no color change was observed in their physical appearance and other physiochemical properties.

\section{DISCUSSION}

Embelin isolated from Embelia ribes is known for its potent biological properties. ${ }^{[1-13]}$ Our earlier studies reported that it has potent antioxidant, analgesic, and anti-inflammatory properties. ${ }^{[6,15]}$ In the present study, we are formulated embelin emulgel and tested for its in vitro antioxidant and anti-inflammatory properties. The embelin showed potent antioxidant activity and incorporated when it was converted into emulgel formulations. The results also well correlate with our earlier studies of antioxidant activity of embelin. ${ }^{[14,15]}$ 
Based on these results, both the formulations (F1 and F2) along with embelin were tested for in vitro anti-inflammatory activity. In the present study, anti-inflammatory activity of embelin and its emulgel formulations was evaluated by determination of inhibition of albumin denaturation and lipoxygenase inhibition. Embelin and its formulated emulgels exhibited a moderate effect in both the tested methods. The observed anti-inflammatory properties of embelin and its formulations may be due to their potent antioxidant nature.

\section{CONCLUSION}

Embelin is a hydrophobic compound with potent antioxidant and anti-inflammatory properties. Since emulgel is helpful in enhancing spreadability, adhesion, viscosity, and extrusion, this novel drug delivery becomes popular. The formulated embelin emulgel showed potent antioxidant and moderate anti-inflammatory properties which is water soluble gel. This embelin emulgel will be further developed into a commercial standard for topical delivery and tested for in vivo studies to confirm its anti-inflammatory properties.

\section{REFERENCES}

1. Bhandari U, Jain N, Pillai KK. Further studies on antioxidant potential and protection of pancreatic betacells by Embelia ribes in experimental diabetes. Exp Diabetes Res 2007;2007:15803.

2. Kapoor VK, Chawla AS, Kumar M, Kumar P. Antiinflammatory agent in Indian laboratories. Indian Drugs 1983;30:481-8.

3. Krishnaswamy M, Purushothaman KK. Antifertility properties of Embelia ribes. Indian J Exp Biol 1980;18:638-9.

4. Radhakrishnan N, Alam M. Antifertility activity of embelin in albino rats. Indian J Exp Biol 1975;13:70-1.

5. Chitra M, Sukumar E, Suja V, Devi CS. Antitumor, antiinflammatory and analgesic property of embelin, a plant product. Chemotherapy 1994;40:109-13.

6. Mahendran S, Badami S, Ravi S, Thippeswamy BS, Veerapur VP. Synthesis and evaluation of analgesic and anti-inflammatory activities of most active free radical scavenging derivatives of embelin-A structure-activity relationship. Chem Pharm Bull (Tokyo) 2011;59:913-9.

7. Joshi R, Kamat JP, Mukherjee T. Free radical scavenging reactions and antioxidant activity of embelin: Biochemical and pulse radiolytic studies. Chem Biol Interact 2007;167:125-34.

8. Singh D, Singh R, Singh P, Gupta RS. Effects of embelin on lipid peroxidation and free radical scavenging activity against liver damage in rats. Basic Clin Pharmacol Toxicol 2009;105:243-8.

9. Kumara Swamy HM, Krishna V, Shankarmurthy K,
Abdul Rahiman B, Mankani KL, Mahadevan KM, et al. Wound healing activity of embelin isolated from the ethanol extract of leaves of Embelia ribes Burm. J Ethnopharmacol 2007;109:529-34.

10. Chitra M, Devi CS, Sukumar E. Antibacterial activity of embelin. Fitoterapia 2003;74:401-3.

11. Mahendran S, Badami S, Maithili V. Evaluation of antidiabetic effect of embelin in alloxan induced diabetes in rats. Biomed Preven Nutri 2011;1:25-31.

12. Mahendran S, Thippeswamy BS, Veerapur VP, Badami S. Anticonvulsant activity of embelin isolated from Embelia ribes. Phytomedicine 2011;18:186-8.

13. Thippeswamy BS, Nagakannan P, Shivasharan BD, Mahendran S, Veerapur VP, Badami S, et al. Protective effect of embelin from Embelia ribes Burm. Against transient global ischemia-induced brain damage in rats. Neurotox Res 2011;20:379-86.

14. Thippeswamy BS, Mahendran S, Biradar MI, Raj P, Srivastava K, Badami S, et al. Protective effect of embelin against acetic acid induced ulcerative colitis in rats. Eur J Pharmacol 2011;654:100-5.

15. Mahendran S, Badami S, Ravi S, Thippeswamy BS, Veerapur VP. Antioxidant, analgesic and antiinflammatory studies of novel ninhydrin adduct of embelin. Pharm Chem J 2011;45:547-51.

16. Mohamed MI. Optimization of chlorphenesin emulgel formulation. AAPS J 2004;6:e26.

17. Rachit K, Deepinder K, Nimrata S, Seema S. Formulation and evaluation of mefenamic acid emulgelfor topical delivery. Saudi Pharm J 2012;20:63-7.

18. Stanos SP. Topical agents for the management of musculoskeletal pain. J Pain Symptom Manage 2007;33:342-55.

19. Panwar A, Upadhyay N, Bairagi M, Gujar S, Darwhekar G, Jain D. Emulgel: A review. Asian J Pharm Life Sci 2011;1:333-44.

20. Effionora A, Harmita DR. Formulation and evaluation of gel and emulgel of chili extract (Capsicum frutescens 1.) as topical dosage forms. Int J Pharm Pharm Sci 2014;6:13-6.

21. Kumar YS, Kumar MM, Anupamaa T, Ashutosh S. Emulgel: A new approach for enhanced topical drug delivery. Int J Curr Pharm Res 2016;9:15-9.

22. Mahendran S, Pavitra S, Afzan M. Formulation and evaluation of novel antiaging cream containing rambutan fruit extract. Int J Pharma Sci Res 2017;8:1056-65.

23. Mahendran S, Syahira AJ. Formulation and evaluation of novel antibacterial and anti-inflammatory cream containing Muntingia calabura Leaves extract. Asian J Pharm Clin Res 2017;10:376-9.

24. Leelaprakash G, Das SM. In-vitro anti-inflammatory activity of methanol extract of Enicostemma axillare. Int J Drug Dev Res 2011;3:189-96.

Source of Support: Nil. Conflict of Interest: None declared. 